\title{
Multivariate Optimization and Validation of an Analytical Method for the Determination of Cadmium in Wines Employing ET AAS
}

\author{
Sérgio L. C. Ferreira, ${ }^{*, a}$ Robson M. de Jesus, ${ }^{a}$ Geraldo D. Matos, ${ }^{a}$ Jailson B. de Andrade, ${ }^{a}$ Roy E. Bruns, ${ }^{b}$ \\ Walter N. L. dos Santos, ${ }^{c}$ Danuza D. Cavalcante, ${ }^{c}$ Maria G. R. Vale ${ }^{d}$ and Morgana B. Dessuy ${ }^{d}$ \\ ${ }^{a}$ Instituto de Química, Universidade Federal da Bahia, 40170-270 Salvador-BA, Brazil \\ ${ }^{b}$ Instituto de Química, Universidade Estadual de Campinas, 13083-970 Campinas-SP, Brazil \\ 'Universidade do Estado da Bahia, 91501-970 Salvador-BA, Brazil \\ ${ }^{d}$ Instituto de Química, Universidade Federal do Rio Grande do Sul, 91501-970 Porto Alegre-RS, Brazil
}

\begin{abstract}
O presente trabalho descreve a otimização e validação de um método para determinação direta de cádmio em amostras de vinho por espectrometria de absorção atômica com atomização eletrotérmica (ET AAS). A otimização foi realizada empregando um planejamento fatorial completo de 2 níveis, incluindo os fatores: tempo (10 s) e temperatura de pirólise $\left(600{ }^{\circ} \mathrm{C}\right)$, temperatura de atomização $\left(1300{ }^{\circ} \mathrm{C}\right)$ e massa de modificador $(15 \mu \mathrm{g})$. Sob as condições otimizadas, foi encontrada uma massa característica de $0,7 \mathrm{pg}$, limite de detecção e quantificação de 0,030 e $0,100 \mu \mathrm{g} \mathrm{\textrm {L } ^ { - 1 }}$, respectivamente, para um volume de amostra de $20 \mu \mathrm{L}$. A precisão foi de 0,30 , 0,37 e $0,49 \%$ (RSD) para amostras de vinho com concentrações de 1,286, 0,266 e $0.356 \mu \mathrm{g} \mathrm{L}^{-1}$, respectivamente. A exatidão da metodologia de determinação direta empregando ET AAS foi avaliada por comparação usando um método de digestão ácida e determinação também por ET AAS para cinco amostras de vinho. O método foi aplicado para determinação de cádmio em 30 amostras de vinhos brasileiros. A concentração de cádmio variou de 0,146 a 1,563 $\mu \mathrm{g} \mathrm{L} \mathrm{L}^{-1}$, cujos valores estão abaixo do nível máximo permitido pela Organização Internacional de Vinha e Vinho (OIV) e pela legislação brasileira, $10 \mu \mathrm{g} \mathrm{\textrm {L } ^ { - 1 }}$.
\end{abstract}

This work describes the optimization and validation of a direct method employing electrothermal atomic absorption spectrometry (ET AAS) for the determination of cadmium in wine. The optimization step was carried out using a two-level full factorial design, involving the followings factors: pyrolysis time $(10 \mathrm{~s})$ and temperature $\left(600{ }^{\circ} \mathrm{C}\right)$, atomization temperature $\left(1300{ }^{\circ} \mathrm{C}\right)$ and modifier mass $(15 \mu \mathrm{g})$. Under the optimized conditions, a characteristic mass of $0.7 \mathrm{pg}$ and limits of detection and quantification of 0.030 and $0.100 \mu \mathrm{g} \mathrm{L}^{-1}$, respectively, were obtained using a sample volume of $20 \mu \mathrm{L}$. The precision expressed as relative standard deviation (RSD \%) was $0.30,0.37$ and $0.49 \%$ for wines with cadmium concentrations of $1.286,0.266$ and $0.356 \mu \mathrm{g} \mathrm{L}^{-1}$, respectively. The accuracy of the new direct determination methodology applying ET AAS was assessed by comparison with an acid digestion methodology, also with determination by ET AAS, using five wine samples. The proposed method was applied for the determination of cadmium in 30 Brazilian wine samples. The cadmium content varied from 0.146 to $1.563 \mu \mathrm{g} \mathrm{L}^{-1}$; all these values are lower than the permissible maximum level stipulated by the International Organization of Vine and Wine (OIV) and also by Brazilian legislation, which is $10 \mu \mathrm{g} \mathrm{L}^{-1}$.

Keywords: cadmium, ET AAS, Brazilian wines, cadmium in Brazilian wines

\section{Introduction}

Wine, a product of yeast fermentation of natural sugars present in grape juice, has been a widely consumed

*e-mail: slcf@ufba.br beverage in many parts of the world for thousands of years with very obvious commercial value and social importance. ${ }^{1,2}$ Numerous studies have shown that the moderate consumption of wine improves good health and longevity. Wine is a complex sample containing organic as well as inorganic substances in an aqueous ethanol 
solution. The composition and the quality of wines can be influenced by many and diverse factors corresponding to the specific production area, such as grape variety, soil and climate, herbicidal treatment, culture, yeast, winemaking practices, transport and storage. ${ }^{3,4} \mathrm{Cadmium}$ is a metal of high toxicity and, nowadays, is ubiquitous in food, water and air. ${ }^{5,6}$ The highest human cadmium exposure comes from tobacco smoke and from ingestion of food and beverages, including wines, most of which arises from the uptake of cadmium by plants from fertilizers, pesticides, fungicides, sewage, sludge, manure and atmospheric deposition. ${ }^{1}$ Cadmium is absorbed more efficiently by the lungs ( 30 to $60 \%$ ) than by the gastrointestinal tract. The most serious chronic effect of oral exposure to cadmium is renal toxicity. ${ }^{7} \mathrm{~A}$ joint FAO/WHO (Food and Agriculture Organization / World Health Organization) expert committee has estimated a provisional tolerable weekly intake of cadmium for an adult to be from 0.4 to $0.5 \mathrm{mg}$. In wines, the permissible maximum level for cadmium has been stipulated by International Organisation of Vine and Wine (OIV) as $10 \mu \mathrm{g} \mathrm{L}^{-1} .{ }^{8}$ Brazilian legislation also limited the cadmium content at this value. ${ }^{9}$

Trace element determination in complex matrices, such as wine, has traditionally been a challenging analytical task because of the potential interference due to concomitants. According to a recent literature survey a wide variety of analytical techniques have been applied to quantify the trace metal content of wine, such as ion chromatography, stripping potentiometry, inductively coupled plasma mass spectrometry, inductively coupled plasma optical emission spectrometry, flame atomic absorption spectrometry, and electrothermal atomic absorption spectrometry (ET AAS). ${ }^{10,11}$ Sample pretreatment is usually required for achieving good accuracy and to destroy the organic matrix and/or to extract the metal ions bound in inorganic and organic complexes. ${ }^{12}$ Besides this, cadmium is present in wine at low concentration and its determination in this kind of sample requires the use of analytical techniques of high sensitivity. In this context, ET AAS is a good choice, because of its good detectivity and its tolerance of inorganic and organic matrices, which should make the direct determination of cadmium in wine without any sample preparation possible. ${ }^{11,13,14}$

Chemometric techniques have been applied in analytical chemistry for evaluation of results and also for optimization of analytical methods. ${ }^{15-19}$ For evaluation, the multivariate analysis techniques: principal component analysis (PCA) and hierarchical cluster analysis (HCA) are the ones that are employed most frequently. ${ }^{20}$ For optimization the most frequently used techniques are: two-level factorial design ${ }^{21,22}$ which is used for preliminary evaluation of effects of factors on the analytical systems and also response surface methodologies that allow the determination of critical conditions. ${ }^{23,24}$ Some authors have used these design techniques for optimization of methods established using ET AAS. Benzo et al. ${ }^{25}$ performed a fractional factorial design involving five factors for the optimization of the experimental conditions for the determination of vanadium in aqueous solutions by ET AAS. Grinberg and Campos used factorial design for optimization of the iridium coating procedure in a method proposed for the determination of lead in whole blood and urine by ET AAS. Employing the conditions optimized, up to 1100 firings were possible with the same coating without sensitivity losses. ${ }^{26}$ Pereira-Filho and coworkers ${ }^{27}$ employed factorial design for optimization of the pyrolysis and atomization temperatures established for the determination of cadmium by ET AAS. All these studies were performed using aqueous solutions. Also, Santos used factorial design for optimization of the instrumental conditions for the determination of several metals in hemodialysis water employing ET $\mathrm{AAS}^{28}$ and Ferreira and co-workers established instrumental conditions for quantification of silicon, arsenic, copper and lead in petroleum derivatives by ET AAS using multivariate optimization techniques. ${ }^{29}$

In the present paper, a procedure for the direct determination of cadmium in wine is proposed using ET AAS. The parameters were optimized by a two-level full factorial design.

\section{Experimental}

\section{Instrumentation}

All measurements were carried out using a ZEEnit 600 atomic absorption spectrometer (Analytik Jena AG, Jena, Germany) equipped with a transverse-heated graphite tube atomizer and Zeeman-effect background correction. Transversely heated pyrolytic graphite coated tubes with PIN platform were used for all determinations. A cadmium hollow cathode lamp (Varian, Mulgrave, Australia) was used as radiation source with a current of $3 \mathrm{~mA}$ (wavelength $228.8 \mathrm{~nm}$, spectral resolution $1.2 \mathrm{~nm}$ ). An MPE 60 furnace autosampler (Analytik Jena) was used for sample introduction. Argon with a purity of $99.997 \%$ (White Martins, Salvador, Brazil) was used as the purge gas with an internal flow rate of $2.0 \mathrm{~L} \mathrm{~min}^{-1}$ during all steps, except during atomization, when the internal flow was stopped. Analytical signals were measured as integrated absorbance, $A_{\text {int }}$. The optimized graphite furnace temperature program used for all determinations is shown in Table 1. 
Table 1. Temperature program used for $\mathrm{Cd}$ determination

\begin{tabular}{lccc}
\hline Step & $\mathrm{T} /{ }^{\circ} \mathrm{C}$ & Ramp $/\left({ }^{\circ} \mathrm{C} \mathrm{s}^{-1}\right)$ & Hold time $/ \mathrm{s}$ \\
\hline Drying & 110 & 15 & 15 \\
Drying & 120 & 10 & 15 \\
Drying & 140 & 5 & 10 \\
Pyrolysis & 600 & 10 & 10 \\
Atomization & 1300 & $\mathrm{FP}^{\mathrm{a}}$ & 8 \\
Cleanout & 2300 & $\mathrm{FP}$ & 5 \\
\hline
\end{tabular}

${ }^{\mathrm{a} F u l l}$ power.

\section{Reagents and solutions}

Deionized water, obtained from a Milli-Q system (Millipore, MA, USA) with a specific resistivity of $18 \mathrm{M} \Omega \mathrm{cm}$, was used to prepare all solutions and standards. All reagents were of analytical grade. The nitric acid solutions used in this work were prepared by appropriate dilution from concentrated nitric acid (Merck, Darmstadt, Germany). The working standards were prepared immediately before use, by serial dilutions from a $1000 \mathrm{mg} \mathrm{L}^{-1}$ cadmium stock solution (Merck) in $0.014 \mathrm{~mol} \mathrm{~L}^{-1}$ nitric acid.

The palladium modifier solution added to samples and standards was prepared by diluting $0.5 \mathrm{~mL}$ of palladium modifier stock solution $\left(10.0 \pm 0.2 \mathrm{~g} \mathrm{~L}^{-1} \mathrm{Pd}\right.$ in $15 \%(\mathrm{v} / \mathrm{v})$ $\mathrm{HNO}_{3}$ ) to $10 \mathrm{~mL}$, resulting in a final concentration of $500 \mathrm{mg} \mathrm{L}^{-1} \mathrm{Pd}$.

\section{Samples}

A total of 30 Brazilian red and white wines from different growing areas were purchased at a local market. Details about the type of grape, etc., are given together with the analytical results in the Results and Discussion section.

\section{Sample preparation using a digester block}

Five selected wine samples were subjected to an acid digestion to evaluate the accuracy of the proposed method. A volume of $5 \mathrm{~mL}$ of wine sample was digested in a digester block with the addition of 10 drops of concentrated nitric acid and $2 \mathrm{~mL}$ of $30 \%$ (v/v) hydrogen peroxide (Merck). The mixture was heated at $150{ }^{\circ} \mathrm{C}$ under reflux for $2 \mathrm{~h}$ using a digester system with a "cold finger" ${ }^{30}$ The residue was diluted to $10 \mathrm{~mL}$ with $0.014 \mathrm{~mol} \mathrm{~L}^{-1}$ nitric acid. All samples were digested in triplicate.

\section{Optimisation strategy}

The experimental conditions of drying time, drying temperature, gas flow and clean step were fixed as recommended by the instrument manufacturer and are shown in Table 1. The optimization step of the factors modifier mass, pyrolysis time, pyrolysis temperature and atomization temperature was carried out using a twolevel full factorial design. The experimental dominions were established according to literature data, previous experiments and are presented in Table 2 as coded and real values. ${ }^{31}$ The integrated absorbance (peak area) was used as response. The evaluation of the results of the factorial design was carried using Analysis of Variance at the 95\% confidence level and also a Pareto Chart. All experiments were made using $20 \mu \mathrm{L}$ of wine sample (without dilution) and in random order. The experimental data were processed using the STATISTICA computer program. ${ }^{32}$

\section{Results and Discussion}

\section{Establishment of the experimental conditions for $\mathrm{Cd}$ determination}

The optimization was carried out using a $\left(2^{4}\right)$ twolevel full factorial design, involving the following factors: pyrolysis time, pyrolysis temperature, atomization temperature and modifier mass. The integrated absorbance (peak area) was used as response. The 16 runs of the factorial design were performed without replicates. Table 2 shows the matrix of the factorial design with real and coded values and the results of the experiments carried out, having absorbance integrated (area peak) as response.

Evaluation of the factorial design as a Pareto chart (Figure 1) demonstrates that, for the experimental dominions established, all factors are significant, and the effect values for these variables are: modifier mass $(+0.00742 \pm 0.00111)$, pyrolysis time $(-0.00645 \pm$ $0.00111)$, pyrolysis temperature $(-0.01832 \pm 0.00111)$ and atomization temperature $(-0.01036 \pm 0.00111)$, with the experimental error being calculated by five replicates of the central point. These results demonstrated that the pyrolysis and atomization temperatures are the most important factors of the process. Considering these results, the instrumental conditions recommended for the method are: modifier mass $(15 \mu \mathrm{g})$, pyrolysis time (10 s), pyrolysis temperature $\left(600{ }^{\circ} \mathrm{C}\right)$ and atomization temperature $\left(1300^{\circ} \mathrm{C}\right)$. The data agree with the results obtained by conventional pyrolysis and atomization curves, which were found using a modifier mass of $15 \mu \mathrm{g}$ and pyrolysis time of $10 \mathrm{~s}$, as shown in Figure 2. 
Table 2. Matrix of the full two-level factorial design $2^{4}(\mathrm{~N}=1)^{*}$

\begin{tabular}{|c|c|c|c|c|c|}
\hline Experiment & $\begin{array}{c}\text { Pyrolysis } \\
\text { Temperature } /{ }^{\circ} \mathrm{C}\end{array}$ & $\begin{array}{l}\text { Pyrolysis } \\
\text { time / s }\end{array}$ & $\begin{array}{c}\text { Atomization } \\
\text { Temperature } /{ }^{\circ} \mathrm{C}\end{array}$ & $\begin{array}{l}\text { Modifier } \\
\text { mass / } \mu \mathrm{g}\end{array}$ & $\begin{array}{c}\text { Integrated } \\
\text { absorbance / s }\end{array}$ \\
\hline 1 & $-1(600)$ & $-1(10)$ & $-1(1300)$ & $-1(5)$ & 0.07677 \\
\hline 2 & $1(800)$ & $-1(10)$ & $-1(1300)$ & $-1(5)$ & 0.05289 \\
\hline 3 & $-1(600)$ & $1(30)$ & $-1(1300)$ & $-1(5)$ & 0.07436 \\
\hline 4 & $1(800)$ & $1(30)$ & $-1(1300)$ & $-1(5)$ & 0.03625 \\
\hline 5 & $-1(600)$ & $-1(10)$ & $1(1500)$ & $-1(5)$ & 0.06372 \\
\hline 6 & $1(800)$ & $-1(10)$ & $1(1500)$ & $-1(5)$ & 0.04699 \\
\hline 7 & $-1(600)$ & $1(30)$ & $1(1500)$ & $-1(5)$ & 0.06137 \\
\hline 8 & $1(800)$ & $1(30)$ & $1(1500)$ & $-1(5)$ & 0.03924 \\
\hline 9 & $-1(600)$ & $-1(10)$ & $-1(1300)$ & $1(15)$ & 0.07714 \\
\hline 10 & $1(800)$ & $-1(10)$ & $-1(1300)$ & $1(15)$ & 0.06716 \\
\hline 11 & $-1(600)$ & $1(30)$ & $-1(1300)$ & $1(15)$ & 0.07568 \\
\hline 12 & $1(800)$ & $1(30)$ & $-1(1300)$ & $1(15)$ & 0.06244 \\
\hline 13 & $-1(600)$ & $-1(10)$ & $1(1500)$ & $1(15)$ & 0.06401 \\
\hline 14 & $1(800)$ & $-1(10)$ & $1(1500)$ & $1(15)$ & 0.05838 \\
\hline 15 & $-1(600)$ & $1(30)$ & $1(1500)$ & $1(15)$ & 0.06150 \\
\hline 16 & $1(800)$ & $1(30)$ & $1(1500)$ & $1(15)$ & 0.04464 \\
\hline 17 & $0(700)$ & $0(20)$ & $0(1400)$ & $0(10)$ & 0.06723 \\
\hline 18 & $0(700)$ & $0(20)$ & $0(1400)$ & $0(10)$ & 0.06759 \\
\hline 19 & $0(700)$ & $0(20)$ & $0(1400)$ & $0(10)$ & 0.06647 \\
\hline 20 & $0(700)$ & $0(20)$ & 0 (1400) & $0(10)$ & 0.06854 \\
\hline 21 & $0(700)$ & $0(20)$ & $0(1400)$ & $0(10)$ & 0.06812 \\
\hline
\end{tabular}

*Real values are in parentheses.

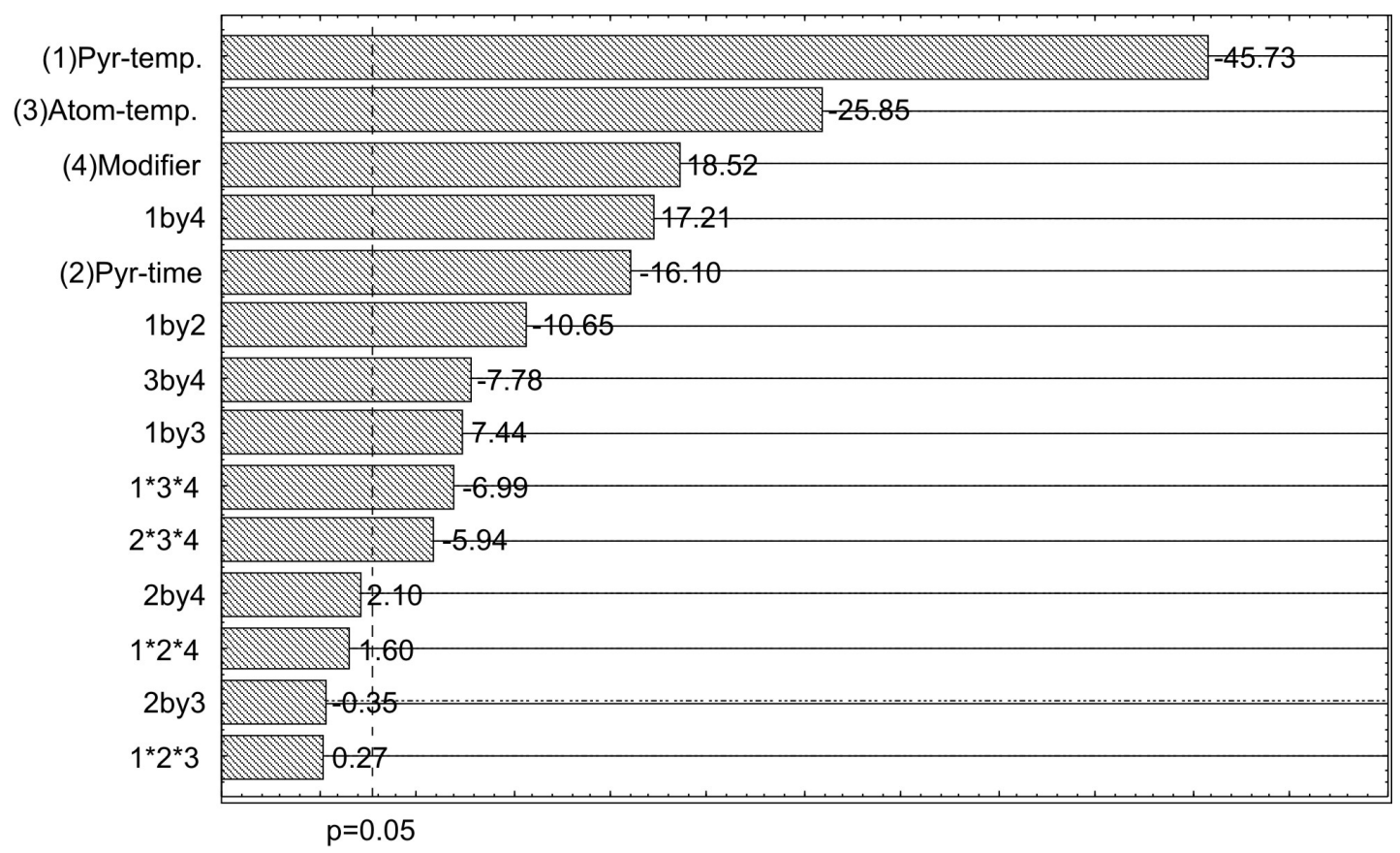

Effect Estimate (Absolute Value)

Figure 1. Pareto chart for the two-level factorial design. 


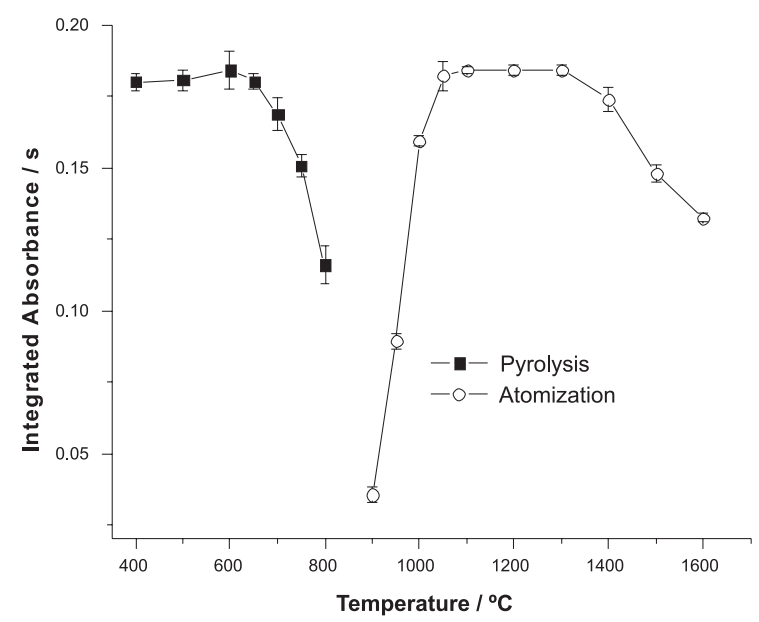

Figure 2. Pyrolysis $\left(\mathrm{Ta}=1200^{\circ} \mathrm{C}\right)$ and atomization $\left(\mathrm{Tp}=600^{\circ} \mathrm{C}\right)$ curves for $20 \mu \mathrm{L}$ of Cabernet Sauvignon wine using $15 \mu \mathrm{g} \mathrm{Pd}$ as chemical modifier $(\mathrm{N}=3)$.

\section{Figures of merit}

Using the experimental conditions established in the optimization step, the method allows the direct determination of cadmium in wine with a characteristic mass of $0.7 \mathrm{pg}$, limit of detection and quantification (calculated as $3 \delta / \mathrm{s}$ and $10 \delta / \mathrm{s}$, where $\delta$ is the standard deviation of the blank solution and s the slope of analytical curve employed) were 0.030 and $0.100 \mu \mathrm{g} \mathrm{L}^{-1}$, respectively, for a sample volume of $20 \mu \mathrm{L} .{ }^{33}$

The slope of the analytical curves established with

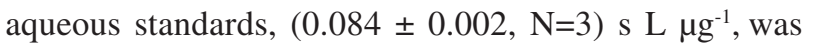
always lower than that obtained for wine samples using the analyte addition technique, although the same modifier was used in all cases. For this reason the slope of the addition curve was determined for six wine samples. The values

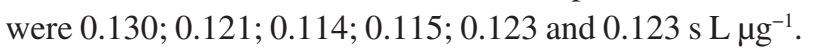
All the other wine samples were analyzed using the average slope of $(0.121 \pm 0.006, \mathrm{~N}=6) \mathrm{s} \mathrm{L} \mu \mathrm{g}^{-1}$ calculated for the six selected samples.

The precision (expressed as relative standard deviation of seven repetitive determinations) was evaluated for three wine samples with cadmium concentrations of 1.29 , 0.27 and $0.36 \mu \mathrm{g} \mathrm{L}^{-1}$, and was $0.30 \%, 0.37 \%$ and $0.49 \%$, respectively. The accuracy was investigated by comparing the results obtained with this method for five wine samples with those found after complete mineralization using acid digestion and determination with ET AAS; the results are presented in Table 3. The linear regression method was used to compare the results obtained with the two methods, and the equation expressed as confidence intervals was:

[Digestion procedure] $=1.20 \pm 0.27$ [Direct method] $0.12 \pm 0.22, r=0.9926$
Table 3. Evaluation of the accuracy of the proposed method $(\mathrm{N}=3)$

\begin{tabular}{lcc}
\hline Wine sample & $\begin{array}{c}\text { Cd concentration } \\
(\text { proposed method }) / \\
\left(\mu \mathrm{g} \mathrm{L}^{-1}\right)\end{array}$ & $\begin{array}{c}\text { Cd concentration (acid } \\
\text { digestion }) /\left(\mu \mathrm{g} \mathrm{L}^{-1}\right)\end{array}$ \\
\hline Dry red 1 & $1.286 \pm 0.001$ & $1.428 \pm 0.008$ \\
Dry White 1 & $0.615 \pm 0.003$ & $0.681 \pm 0.001$ \\
Sweet White 1 & $0.706 \pm 0.003$ & $0.713 \pm 0.006$ \\
Sweet White 2 & $0.766 \pm 0.001$ & $0.759 \pm 0.001$ \\
Dry red 2 & $0.598 \pm 0.002$ & $0.563 \pm 0.008$ \\
\hline
\end{tabular}

These results demonstrate that the calculated slope and intercept do not differ significantly from the "ideal" values of 1 and 0 , respectively, and that there is no evidence for a systematic difference between the two methods for the determination of cadmium in wine.

Using the optimized conditions up to 400 firings were possible with the same tube without sensitivity losses.

\section{Application}

The proposed method was applied for the determination of cadmium in 30 Brazilian wine samples from the following regions: Vale do São Francisco, Bento Gonçalves, Campanha, Caxias do Sul, Santana do Livramento and São Bernardo do Campo. All samples were analyzed in triplicate. The results are shown in Table 4; the cadmium content varied from 0.146 to $1.56 \mu \mathrm{g} \mathrm{L}^{-1}$, with an average concentration of $0.460 \mu \mathrm{g} \mathrm{L}^{-1}$. These values are in agreement with data reported in the literature for cadmium content in wines. ${ }^{11,34,35}$ All values found in this study were significantly lower than the permissible maximum level stipulated by the International Organization of Vine and Wine (OIV) and also by Brazilian legislation.

\section{Conclusions}

The experimental conditions established by two-level full factorial design for the determination of cadmium employing ET AAS are very similar to the conditions obtained using univariate methodology establishing conventional pyrolysis and atomization curves. However, optimization using factorial design makes the determination of the experimental conditions with fewer experiments possible, obtaining information for all the four factors involved in the process.

The wine matrix has an effect on the integrated absorbance signal of cadmium and also on the slope of the calibration curves. This effect is significantly different for undigested and acid digested wine. It is 
Table 4. Determination of cadmium in Brazilian wine samples $(\mathrm{N}=3)$

\begin{tabular}{|c|c|c|c|c|}
\hline Sample & Wine & Origin & Grape type & $\begin{array}{c}\text { Concentration } \\
\mathrm{Cd}(\mathrm{n}=3) /\left(\mu \mathrm{g} \mathrm{L}^{-1}\right)\end{array}$ \\
\hline 1 & Dry red & Vale do São Francisco & Cabernet Sauvignon & $1.286 \pm 0.001$ \\
\hline 2 & Dry red & Vale do São Francisco & Cabernet Sauvignon & $1.563 \pm 0.001$ \\
\hline 3 & Dry red & Vale do São Francisco & Shiraz & $0.356 \pm 0.001$ \\
\hline 4 & Dry red & Vale do São Francisco & Cabernet Sauvignon & $0.266 \pm 0.002$ \\
\hline 5 & Dry red & Vale do São Francisco & Tannat & $0.546 \pm 0.004$ \\
\hline 6 & Dry red & Bento Gonçalves & Cabernet Sauvignon & $0.556 \pm 0.002$ \\
\hline 7 & Sweet red & Vale do São Francisco & Cabernet Sauvignon and Shiraz & $0.485 \pm 0.002$ \\
\hline 8 & Sweet red & Caxias do Sul & - & $0.377 \pm 0.004$ \\
\hline 9 & Sweet red & Caxias do Sul & - & $0.356 \pm 0.001$ \\
\hline 10 & Dry White & Bento Gonçalves & Chardonnay & $0.615 \pm 0.003$ \\
\hline 11 & Dry White & Bento Gonçalves & - & $0.468 \pm 0.002$ \\
\hline 12 & Sweet White & Bento Gonçalves & - & $0.706 \pm 0.003$ \\
\hline 13 & Sweet White & Vale do São Francisco & Sauvignon Blanc and Chardonnay & $0.766 \pm 0.001$ \\
\hline 14 & Sweet White & Caxias do Sul & - & $0.333 \pm 0.001$ \\
\hline 15 & Sweet White & Caxias do Sul & - & $0.364 \pm 0.001$ \\
\hline 16 & Sweet white & Vale do São Francisco & Moscato Canelli & $0.308 \pm 0.006$ \\
\hline 17 & Dry white & Vale do São Francisco & Chenin Blanc & $0.306 \pm 0.003$ \\
\hline 18 & Dry white & Campanha & Sauvignon Blanc & $0.197 \pm 0.001$ \\
\hline 19 & Dry red & Santana do Livramento & Cabernet Franc & $0.414 \pm 0.001$ \\
\hline 20 & Dry red & Caxias do Sul & Merlot & $0.461 \pm 0.002$ \\
\hline 21 & Dry red & Caxias do Sul & Tannat & $0.462 \pm 0.002$ \\
\hline 22 & Dry red & Bento Gonçalves & Gamay & $<0.100$ \\
\hline 23 & Dry red & Bento Gonçalves & Merlot & $0.598 \pm 0.002$ \\
\hline 24 & Dry white & Bento Gonçalves & Chardonnay & $0.307 \pm 0.001$ \\
\hline 25 & Dry red & Bento Gonçalves & Cabernet Sauvignon, Merlot and Pinot Noir & $0.146 \pm 0.001$ \\
\hline 26 & Dry white & Campanha & Riesling & $0.338 \pm 0.001$ \\
\hline 27 & Dry red & Caxias do Sul & Cabernet Sauvignon & $0.209 \pm 0.002$ \\
\hline 28 & Dry red & São Bernardo do Campo & Cabernet Franc & $0.221 \pm 0.001$ \\
\hline 29 & Sweet red & Bento Gonçalves & Cabernet Franc & $0.507 \pm 0.001$ \\
\hline 30 & Dry red & Santana do Livramento & Merlot & $0.289 \pm 0.002$ \\
\hline
\end{tabular}

not related to the alcohol content and it was very similar for all wines investigated in this study. Hence it was possible to correct for this effect using the addition calibration technique, i.e., using the average slope of the analyte addition curves of a few selected wine samples for calibration.

The cadmium content found in Brazilian wines was always lower than the maximum permissible level stipulated by the International Organization of Vine and Wine (OIV) and also by Brazilian legislation.

\section{Acknowledgments}

The authors are grateful to the Fundação de Amparo à Pesquisa do Estado da Bahia (FAPESB), the Conselho Nacional de Desenvolvimento Científico e Tecnológico
(CNPq) and the Coordenação de Aperfeiçoamento de Pessoal de Nível Superior (CAPES) for providing grants and fellowships and for financial support.

\section{References}

1. Pohl, P; TrAC, Trends Anal. Chem. 2007, 26, 941.

2. Dessuy, M. B.; Vale, M. G. R.; Souza, A. S.; Ferreira, S. L. C.; Welz, B.; Katskov, D. A.; Talanta 2008, 74, 1321.

3. Moreno, I. M.; González-Weller, D.; Gutierrez, V.; Marino, M.; Cameán, A. M.; González, A. G.; Hardisson, A.; Microchem. J. 2008, $88,56$.

4. Ferreira, S. L. C.; Souza, A. S.; Brandão, G. C.; Ferreira, H. S.; dos Santos, W. N. L.; Pimentel, M. F.; Vale, M. G. R.; Talanta 2008, 74, 699.

5. Ensafi, A. A.; Shiraz, A. Z.; J. Braz. Chem. Soc. 2008, 19, 11. 
6. Cesarino, I.; Marino, G.; Matos, J. D. R.; Cavalheiro, E. T. G.; J. Braz. Chem. Soc. 2007, 18, 810.

7. Friberg, L.; Kjellstrom, T.; Nordberg, G.; Piscator, M. In Handbook on the Toxicology of Metals; Friberg, L., ed.; Elsevier: Amsterdam, 1979, p. 355.

8. OIV-International Organisation of Vine and Wine; Code Sheet, $1^{\text {st }}$ ed., 2008.

9. Ministry of Agriculture; Federal Decree N. 99,066, Brazil, 1990.

10. Krystyna, P.; Crit. Rev. Anal. Chem. 2004, 34, 69.

11. Ajtony, Z.; Szoboszlai, N.; Suskó, E. K.; Mezei, P.; György, K.; Bencs, L.; Talanta 2008, 76, 627.

12. Buldini, P. L.; Cavalli, S.; Sharma, J. L.; J. Agric. Food Chem. 1999, 47, 1993.

13. Kim, M.; Food Addit. Contam. 2004, 21, 154.

14. Farinas, M. V.; Garcia, J. B.; Martin, S. G.; Crecente, R. P.; Latorre, C. H.; Anal. Chim. Acta 2007, 591, 231.

15. Oliveira, A. M.; Silva, G. A.; Poppi, R. J.; Augusto, F.; J. Braz. Chem. Soc. 2008, 19, 1041.

16. Uliana, C. V.; Riccardi, C. S.; Tognolli, J. O.; Yamanaka, H.; J. Braz. Chem. Soc. 2008, 19, 782.

17. Amorim, V. R.; Polito, W. L.; Gomes Neto, J. A.; J. Braz. Chem. Soc. 2007, 18, 47.

18. dos Santos, J. S.; dos Santos, N. S.; dos Santos, M. L. P.; dos Santos, S. N.; Lacerda, J. J. D. J.; J. Braz. Chem. Soc. 2008, 19, 502 .

19. Araújo, R. G. O.; Macedo, S. M.; Kom, M. D. G. A.; Pimentel, M. F.; Bruns, R. E.; Ferreira, S. L. C.; J. Braz. Chem. Soc. 2008, $19,935$.

20. Panero, F. S.; da Silva, H. E. B.; Microchem. J. 2008, 88 , 194.

21. Massart, D. L.; Vandeginste, B. G. M.; Buydens, L. M. C.; de Jong, S.; Lewi, P. J.; Smeyers-Verbeke, J. In Handbook of Chemometrics and Qualimetrics: Part A; Elsevier: Amsterdam, 1977.
22. Barros Neto, B.; Scarmínio, I. S.; Bruns, R. E.; Planejamento e Otimização de Experimentos; Editora da UNICAMP: Campinas, 1995.

23. Ferreira, S. L. C.; dos Santos, W. N. L.; Quintella, C. M.; Barros Neto, B.; Bosque-Sendra, J. A.; Talanta 2004, 63, 1061.

24. Ferreira, S. L. C.; Bruns, R. E.; Ferreira, H. S.; Matos, G. D.; David, J. M.; Brandão, G. C.; da Silva, E. G. P.; Portugal, L. A.; dos Reis, P. S.; Souza, A. S.; dos Santos, W. N. L.; Anal. Chim. Acta 2007, 597, 179.

25. Benzo, Z.; Monteiro, T.; Quintal, M.; Sierraalta, A.; Ruette, F.; J. Anal. At. Spectrom. 1996, 11, 445.

26. Grinberg, P.; Campos, R. C.; Spectrochim. Acta, Part B 2001, 56, 1831.

27. Pereira-Filho, E. R.; Poppi, R. J.; Arruda, M. A. Z.; Quim. Nova 2002, 25, 246.

28. dos Santos, L. M. G.; Quim. Nova 2008, 31, 975.

29. Ferreira, S. L. C.; Korn, M. D. G. A.; Ferreira, H. S.; da Silva, E. G. P.; Araújo, R. G. O.; Souza, A. S.; Macedo, S. M.; Lima, D. C.; de Jesus, R. M.; Amorim, F. A. C.; Bosque-Sendra, J. M.; Appl. Spectrosc. Rev. 2007, 42, 475.

30. Silva-Filho, E. V.; Sella, S. M.; Spinola, E. C.; Santos, I. R.; Machado, W.; Lacerda, L. D.; Microchem. J. 2006, 82, 196.

31. Fernandes, K. G.; de Moraes, M.; Gomes Neto, J. A.; Nóbrega, J. A.; Oliveira, P.V.; Analyst 2002, 127, 157.

32. Statistica for Windows; StatSoft, Inc.: Tulsa, USA, 1999.

33. IUPAC Analytical Chemistry Division; Spectrochim. Acta B 1978, 33, 242.

34. Jaganathan, J.; Reisig, A. L.; Dugar, S. M.; Microchem. J. 1997, $56,221$.

35. Freschi, G. P. G.; Dakuzaku, C. S.; de Moraes, M.; Nóbrega. J. A.; Gomes Neto, J. A.; Spectrochim. Acta, Part B 2001, 56, 1987.

Received: November 17, 2008

Web Release Date: May 6, 2009

FAPESP helped in meeting the publication costs of this article. 